\title{
The Striatal Mosaic in Primates: Striosomes and Matrix Are Differentially Enriched in Ionotropic Glutamate Receptor Subunits
}

\author{
Lee J. Martin, ${ }^{1,4}$ Craig D. Blackstone, ${ }^{5}$ Richard L. Huganir, ${ }^{3,5}$ and Donald L. Price ${ }^{1,2,3,4}$ \\ Departments of ${ }^{P}$ Pathology, ${ }^{2}$ Neurology, and ${ }^{3}$ Neuroscience, the ${ }^{4}$ Neuropathology Laboratory, and the ${ }^{5}$ Howard Hughes \\ Medical Institute, The Johns Hopkins University School of Medicine, Baltimore, Maryland 21205
}

The cellular and subcellular distributions of the ionotropic $\alpha$-amino-3-hydroxy-5-methyl-4-isoxazole propionic acid (AMPA)-preferring glutamate receptor (GluR) in monkey striatum were demonstrated immunocytochemically using anti-peptide antibodies to individual subunits of the AMPA receptor. These antibodies specifically recognize GluR1, GluR4, and an epitope common to GluR2 and GluR3 (designated as GluR2/3). On immunoblots, the antibodies detect proteins ranging from 102 to $108 \mathrm{kDa}$ in total homogenates of monkey striatum, hippocampus, and cerebellum. By immunoblotting, GluR1 and GluR2/3 are considerably more abundant than GluR4 in the caudate nucleus. Within the caudate nucleus, putamen, and nucleus accumbens, numerous neuronal perikarya, dendrites, and spines show GluR1 and GluR2/3 immunoreactivities. GluR1- and GluR2/3-enriched striatal neurons have the morphology, transmitter specificity, and distribution of medium-sized (10-20 $\mu \mathrm{m})$ spiny neurons; large (20-60 $\mu \mathrm{m})$ round neurons exhibit GluR4 immunoreactivity. GluR1 immunoreactivity, but not GluR2/3 or GluR4 immunoreactivity, is more intense in the ventral striatum (i.e., nucleus accumbens) than in the dorsal striatum, and GluR1 is enriched within dendritic spines in the neuropil of the nucleus accumbens and striosomes in the dorsal striatum. In the caudate nucleus, these patches of dense GluR1 immunoreactivity align with regions low in calcium binding protein immunoreactivity and high in substance P immunoreactivity. Within striosomes, GluR1 immunoreactivity is more abundant than GluR2/3 immunoreactivity; GluR4 immunoreactivity is sparse in striosomes, but the matrix contains large, GluR4-positive cholinergic neurons. This study demonstrates that, within monkey striatum, subunits of ionotropic AMPA GluR have differential distributions within striosomes and matrix. Furthermore, the results suggest that neurons within striatal striosomes and matrix may express different combinations of GluR subunits, thus forming receptors with different channel properties and having con-

\footnotetext{
Received March 9, 1992; revised Aug. 11, 1992; accepted Aug. 24, 1992.

We thank Dr. Linda C. Cork for providing monkey tissue and the Baltimore Zoological Society for their cooperation. The excellent technical assistance of Ms. Judith Van Lare and Mr. Wayne Voris is greatly appreciated. This work was supported by grants from the U.S. Public Health Service (NIH NS 07179, NS 20471, AG 05146), an MSTP training grant (GM 07309), and the Howard Hughes Medical Institute. D.L.P. is the recipient of a Javits Neuroscience Investigator Award (NIH NS 10580) and a Leadership and Excellence in Alzheimer's Disease (LEAD) award (NIA AG 07914).

Correspondence should be addressed to Lee J. Martin, Ph.D., Neuropathology Laboratory, The Johns Hopkins University School of Medicine, 558 Ross Research Building, 720 Rutland Avenue, Baltimore, MD 21 205-2196.

Copyright (C) 1993 Society for Neuroscience $0270-6474 / 93 / 130782-11 \$ 05.00 / 0$
}

sequences that may be relevant physiologically and pathophysiologically. Neurons within these two striatal compartments may have different roles in the synaptic plasticity of motor systems.

[Key words: $\alpha$-amino-3-hydroxy-5-methyl-4-isoxazole propionic acid (AMPA) receptor, caudate nucleus, excitatory amino acids, patch/matrix, putamen, striosome]

The mammalian striatum exhibits a modular organization, with some populations of neurons residing predominantly within either the striosome (patch) compartment or within the matrix compartment (Goldman and Nauta, 1977; Graybiel and Ragsdale, 1978; Goldman-Rakic, 1982; Gerfen, 1985; Gerfen et al., 1987; Graybiel, 1990; Giménez-Amaya and Graybiel, 1991; Martin et al., 1991a). In primates, these two regions are delineated on the basis of cytoarchitecture, chemoarchitecture, and connectivity. For example, within the caudate nucleus, islands of neurons are present (Goldman-Rakic, 1982; Martin et al., $1991 \mathrm{a})$, and these striosomes are enriched in immunoreactivity for substance P (Beach and McGeer, 1984; Haber and Watson, 1985; Martin et al., 1991a) and enkephalin (Haber and Elde, 1982; Graybiel and Ragsdale, 1983; Martin et al., 1991a). Striosomes receive projections from medial limbic cortex (Gerfen, 1984, 1989; Donoghue and Herkenham, 1986), amygdala (Russchen et al., 1985; Ragsdale and Graybiel, 1988), and dopaminergic neurons within ventral densocellular areas of A9 (Gerfen et al., 1987; Langer and Graybiel, 1989). Striosomal neurons preferentially project to the substantia nigra pars compacta (Gerfen, 1984). In contrast, the striatal matrix is relatively enriched in AChE (Graybiel and Ragsdale, 1978, 1983), calcium-binding protein (calbindin-D28), ChAT, and tyrosine hydroxylase immunoreactivities (Gerfen et al., 1985; Graybiel et al., 1986, 1987; Martin et al., 1991a); it receives projections from sensory, motor, supplementary motor, and association neocortices (Goldman and Nauta, 1977; Ragsdale and Graybiel, 1981; Graybiel and Ragsdale, 1983; Selemon and GoldmanRakic, 1985), thalamic intralaminar nuclei (Herkenham and Pert, 1981), and dopaminergic neurons within A8, A10, and dorsal A9 (Gerfen et al., 1987; Langer and Graybiel, 1989). Neurons within the matrix project to the globus pallidus and related structures (Kawaguchi et al., 1990; Giménez-Amaya and Graybiel, 1991).

Within the striatum, some neurotransmitter receptors are also arranged in compartments. For example, $\mu$-opiate receptors (Atweh and Kuhar, 1977; Herkenham and Pert, 1981; Hamel and Beaudet, 1984; Gerfen et al., 1987), dopamine D1 receptors (Besson et al., 1988), and cholinergic Ml binding sites (Nastuk 
and Graybiel, 1988) are enriched in striosomes, whcreas dopamine D2 receptors predominate within the matrix (Joyce et al., 1986). Although the distributions of glutamatergic corticostriatal and thalamostriatal terminal fields are organized within the framework of the striatal mosaic (Goldman and Nauta, 1977; Donoghue and Herkenham, 1986; Gerfen, 1989; Ragsdale and Graybiel, 1990), in vitro autoradiographic studies do not show clear compartmental distributions of glutamate receptor (GluR) binding sites within the striatum (Monaghan and Cotman, 1982; Unnerstall and Wamsley, 1983; Monaghan et al., 1984; Cha et al., 1988; Young et al., 1990). GluR that elicit rapid, excitatory, postsynaptic responses in neurons are ligand-gated ion channel receptors and are classified into three pharmacologically distinct subtypes: NMDA receptors, kainate (KA) receptors, and $\alpha$-amino-3-hydroxy-5-methyl-4-isoxazole propionic acid (AMPA) receptors (Monaghan et al., 1989; Watkins et al., 1990; Gasic and Heinemann, 1991). These receptors arc oligomers, most likely pentamers, of homologous subunits (Gasic and Heinemann, 1991; Wenthold et al., 1992). Recently, seven subunits of non-NMDA GluR subunits have been identified by molecular cloning. GluR1-GluR4 (also designated GluR-A to GluR-D) are AMPA receptor subunits; GluR5, GluR6, and KA1 are KA receptor subunits (Hollmann et al., 1989; Bettler et al., 1990; Boulter et al., 1990; Keinänen et al., 1990; Egebjerg et al., 1991; Werner et al., 1991). To reexamine the organization of GluR in the context of striatal striosome-matrix compartments, we used sensitive site-directed antibodies that have been shown to recognize individual subunits of the AMPA-preferring GluR in rat and human brains (Blackstone et al., 1992a,b; Martin et al., in press). Our immunocytochemical results demonstrate, for the first time, that these AMPA receptor subunits are enriched differentially within the striosome and matrix compartments of the primate striatum.

\section{Materials and Methods}

Polyclonal anti-peptide antibodies. Antisera were generated in New Zealand White rabbits (Hazleton, Denver, PA) against synthetic peptides specific for GluR 1, GluR4, and a domain of GluR2 conserved in GluR3 (denoted GluR2/3), as previously described (Blackstone et al., 1992a,b). These peptides correspond to the C-terminus of each of these proteins, as shown in Figure 1. The crude antisera were affinity purified (Blackstone et al., 1992a) prior to their use in immunoblotting or immunocytochemistry.

Preparation of tissue. The brains of four adult male rhesus monkeys (Macaca mulatta) and one adult male lion-tailed macaque (Macaca silenus) were used in this study. All monkeys were restrained with ketamine and deeply anesthetized with sodium pentobarbital before perfusion. Two rhesus monkeys were perfused with $0.9 \%$ normal saline followed by $4 \%$ paraformaldehyde prepared in $0.1 \mathrm{M}$ sodium phosphate buffer ( $\mathrm{pH}$ 7.4). After perfusion, the brains were cut into $1 \mathrm{~cm}$ slabs and were postfixed $(2 \mathrm{hr})$. Two rhesus monkeys were perfused briefly with only $0.9 \%$ buffered saline; the brains were removed rapidly and blocked coronally. One brain was immersion fixed $\left(8 \mathrm{hr}\right.$ at $\left.4^{\circ} \mathrm{C}\right)$ in $5 \%$ acrolein (Aldrich, Milwaukee, WI) prepared in $0.1 \mathrm{M}$ phosphate buffer; the other brain was not fixed and was quickly frozen under pulverized dry ice. The lion-tailed macaque was perfused with $4 \%$ paraformaldehyde; the brain was immediately cut into $3-\mathrm{mm}$-thick slabs, which were postfixed $(2 \mathrm{hr})$ in $4 \%$ paraformaldehyde, $0.5 \%$ glutaraldehyde and subsequently transferred to $4 \%$ paraformaldehyde, $0.1 \%$ glutaraldehyde overnight. Following fixation, all brain samples were rinsed thoroughly in phosphate buffer and were either cryoprotected $\left(24 \mathrm{hr}\right.$ at $\left.4^{\circ} \mathrm{C}\right)$ in buffered $20 \%$ glycerol or stored in buffer.

Preparation of monkey brain homogenates, gel electrophoresis, and immunoblotting. For preparation of tissue homogenates, dissected samples of unfixed frozen brain were thawed on ice and then homogenized with a Brinkmann Polytron in an ice-cold buffer consisting of $20 \mathrm{~mm}$ Tris- $\mathrm{HCl}(\mathrm{pH} 7.4), 10 \%(\mathrm{w} / \mathrm{v})$ sucrose, $20 \mathrm{U} / \mathrm{ml}$ Trasylol (aprotinin), 20

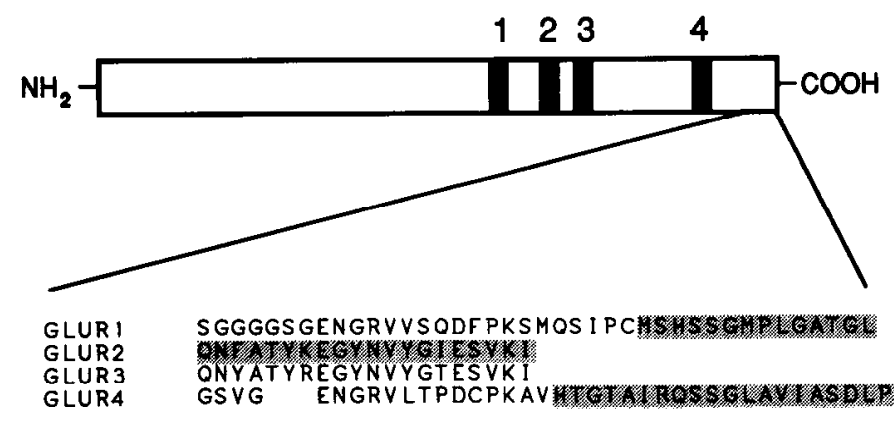

Figure 1. Schematic diagram showing the structure of the AMPA receptor subunits GluR 1-GluR4. The four putative transmembrane domains are represented in black. The amino acid sequence at the C-terminus of each of these subunits is shown (one-letter amino acid code), with peptides selected for antisera production shaded. Note the near identity between C-termini of GluR2 and GluR3.

$\mu \mathrm{g} / \mathrm{ml}$ antipain, $20 \mu \mathrm{g} / \mathrm{ml}$ leupeptin, $1 \mathrm{~mm}$ EDTA, and 5 mм EGTA. Homogenates were stored frozen at $10 \mathrm{mg}$ of protein $/ \mathrm{ml}$ at $-70^{\circ} \mathrm{C}$.

Monkey hippocampal, striatal (i.e., caudate nucleus), and cerebellar homogenates were subjected to SDS-PAGE ( $8 \%$ polyacrylamide gels) and transferred to polyvinylidene fluoride (PVDF) membrancs (Immobilon P, Millipore, Bedford, MA) by electroblotting (30 V, overnight). Next, the blots were blocked at room temperature with $0.5 \%$ nonfat dry milk (Carnation) and $0.1 \%$ Tween 20 in Tris-buffered saline (TBS: $50 \mathrm{~mm}$ Tris- $\mathrm{HCl}, \mathrm{pH} 7.2$, and $150 \mathrm{~mm} \mathrm{NaCl}$ ) for $1 \mathrm{hr}$. After several washes with blocking buffer, the blots were incubated with horseradish peroxidase-conjugated donkey anti-rabbit IgG (1:5000 in blocking buffer; Amersham) for $1 \mathrm{hr}$. Following several washes with TBS, immunoreactive proteins were visualized with enhanced chemiluminescence (Amersham), as recommended by the manufacturer.

Immunocytochemistry. Coronal sections $(40 \mu \mathrm{m})$ through the striatum (mid-level of the nucleus accumbens to posterior putamen) were cut on a sliding microtome or a Vibratome and placed in TBS (pH 7.2). Sections intended solely for light microscopy were permeabilized $(30 \mathrm{~min})$ in $0.4 \%$ Triton X-100 (TX)/TBS, whereas sections intended for electron microscopy were treated $(10 \mathrm{~min})$ with $0.08 \%$ TX/TBS or with no TX. Subsequent immunocytochemical steps were identical for both groups of sections, with the exception that sections for electron microscopy were not further exposed to TX. Sections were preincubated $(1 \mathrm{hr})$ in $4 \%$ normal goat serum or nonfat dry milk diluted in $0.1 \%$ TX/TBS and were incubated $\left(48 \mathrm{hr}\right.$ at $\left.4^{\circ} \mathrm{C}\right)$ in affinity-purified rabbit polyclonal antiGluR1, -GluR2/3, or -GluR4 antibodies (immunoglobulin concentrations of $0.5 \mu \mathrm{g} / \mathrm{ml}$ ). The production, characterization, and subunit specificity of these antibodies have been reported previously (Blackstone et al., 1992a,b). Control sections were incubated with GluR antibodies adsorbed overnight with an excess $(10-30 \mu \mathrm{g} / \mathrm{ml})$ of corresponding synthetic GluR peptide, with comparable amounts of rabbit IgG, or with primary antibody omitted. Following incubation, sections were rinsed (30 min) in TBS, incubated (1 hr) with goat anti-rabbit immunoglobulin (Cappel, West Chester, PA) diluted at 1:100, rinsed (30 min) in TBS, and incubated $(1 \mathrm{hr})$ with rabbit peroxidase-antiperoxidase (PAP) complex (Sternberger Monoclonals, Baltimore, MD) diluted at 1:200. As additional controls, some sections were incubated in solutions lacking secondary antibody and PAP. After the final incubation, sections were rinsed $(30 \mathrm{~min})$ in TBS and developed using a standard diaminobenzidine reaction. Adjacent sections through the striatum were also stained for calbindin D-28 and substance P, markers that, in monkey, identify matrix and striosome compartments, respectively (Martin et al., 1991a). In addition, using diaminobenzidine and benzidine dihydrochloride as chromagens (Levey et al., 1986), selected sections of the striatum were prepared to establish whether GluR subunits colocalized with ChAT, substance $P$, and leucine-enkephalin. Monoclonal antibodies that recognize ChAT (Incstar, Stillwater, MN), substance P (Scra Lab., Wcstbury, NY), and leucine-enkephalin (Sera Lab.) were used. Representative sections were plotted using a computer-assisted plotting system (Martin et al., 199 lb) to quantitate the proportions of ChAT-positive neurons that are GluR positive.

Samples $\left(3 \mathrm{~mm}^{2}\right)$ for electron microscopy were taken from the immunocytochemically processed Vibratome sections. In sections of monkey striatum, striosomes are visible macroscopically; therefore, strio- 


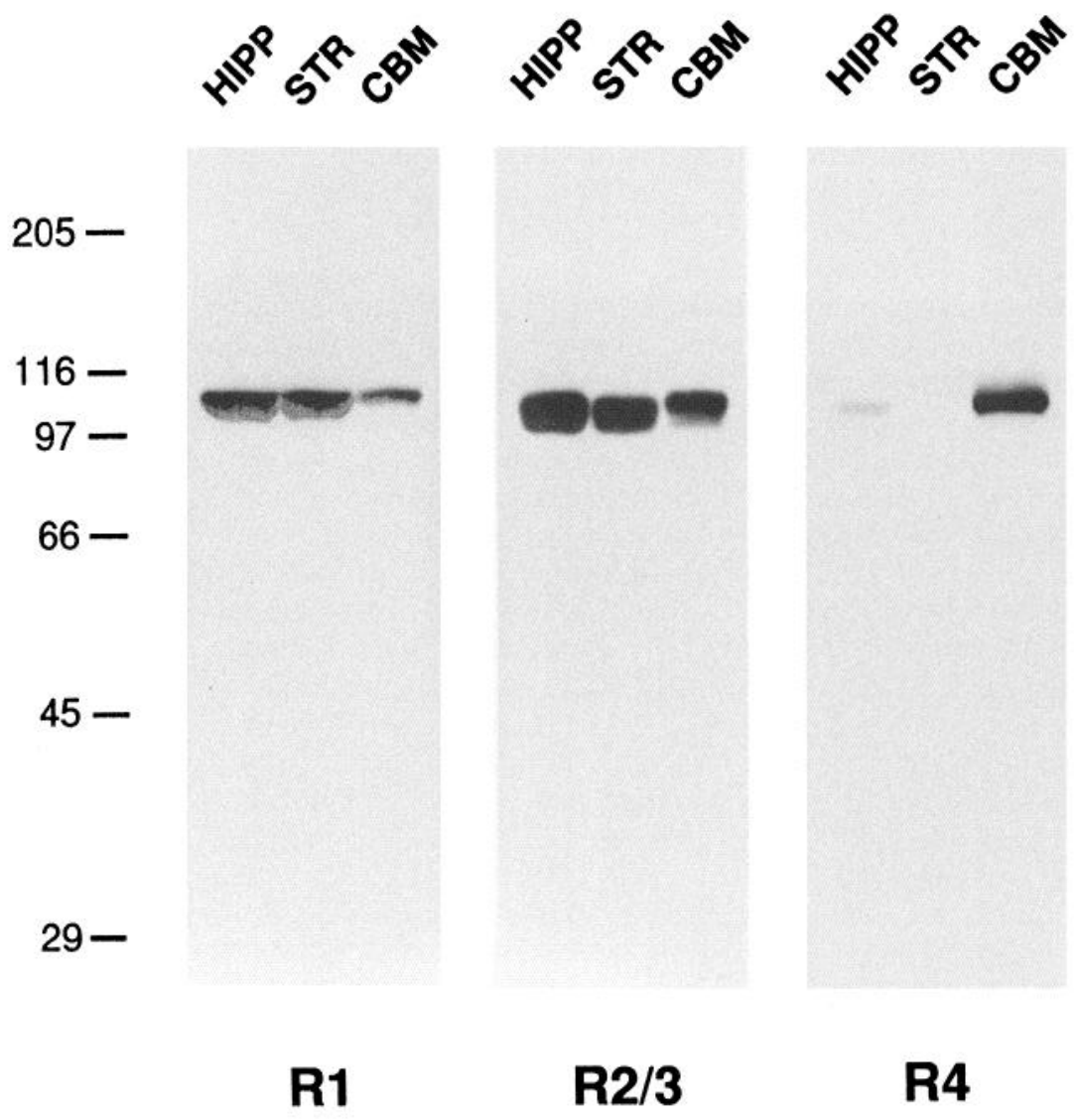

Figure 2. The specificity of anti-GluR anti-peptide antibodies as demonstrated by immunoblotting. Whole tissue homogenates (approximately $50 \mu \mathrm{g}$ of protein/lane) prepared from monkey hippocampus $(H I P P)$, striatum $(S T R)$, and cerebellum $(C B M)$ were subjected to SDS-PAGE and immunoblotted with antibodies $(0.5 \mu \mathrm{g} \mathrm{IgG/ml})$ against GluR1 (RI), GluR2/3 (R2/3), and GluR4 $(R 4)$ as indicated. Faint GluR4 immunoreactivity was detected in striatum at longer exposures. The sizes of protein standards (in $\mathrm{kDa}$ ) are indicated.

somes and matrix were sampled from these sections. These samples were treated $(1 \mathrm{hr}$ ) with $2 \%$ osmium tetroxide, dehydrated, stained en bloc with uranyl acetate, and flat embedded in resin on glass slides. Plastic-embedded sections were mounted on an Araldite block and cut into semithin $(1 \mu \mathrm{m})$ and ultrathin (gold-to-silver interference color; 70$90 \mathrm{~nm}$ ) sections. Ultrathin sections with and without lead citrate staining were viewed with a Philips CM12 or JOEL 100 S electron microscope.

\section{Results}

\section{Immunoblotting}

Each of the anti-peptide antibodies detected distinct proteins, ranging from 102 to $108 \mathrm{kDa}$, in homogenates from monkey hippocampus, striatum, and cerebellum (Fig. 2). These sizes and distributions were similar to those of the AMPA receptor subunits in rat and human brains (Blackstone et al., 1992a,b; Wenthold et al., 1992). Some of the GluR $2 / 3$ immunoreactivity in the cerebellum may be caused by detection of the recently reported AMPA receptor subunit GluR4c that has a C-terminus very similar to those of GluR2 and GluR3, which is highly enriched in cerebellum (Gallo et al., 1992). The GluR1 and GluR2/3 antibodies revealed abundant immunoreactivity in monkey striatum, whereas GluR4 levels are much lower.

\section{Immunocytochemistry}

By immunocytochemical localization, individual GluR subunits showed specific and unique patterns of immunoreactivity within monkey striatum (Figs. 3, 4; see also Fig. 6). Patterns of immunoreactivity were similar within the striatum of all four monkeys examined. Different fixation protocols did not alter appreciably the patterns of immunocytochemical staining within the

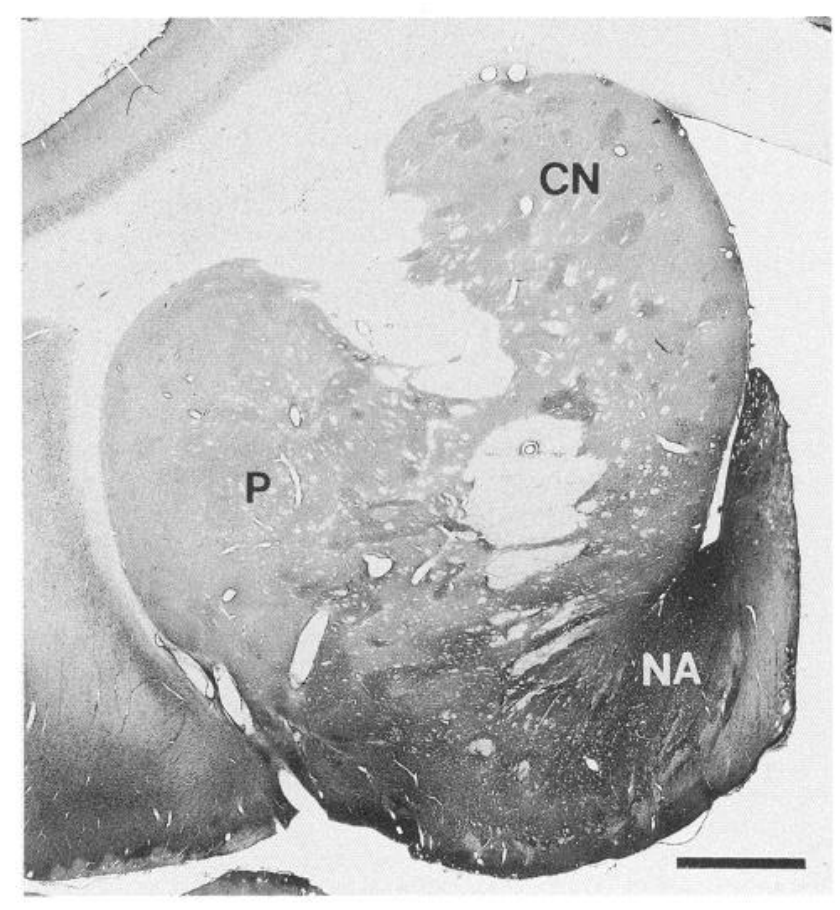

Figure 3. Macrophotograph depicting the localization of AMPA receptor subunit immunoreactivity within rhesus monkey striatum. GluR1 immunoreactivity has a patchy distribution within the caudate nucleus $(C N)$ and putamen $(P)$. The nucleus accumbens $(N A)$ is more enriched in GluR1 immunoreactivity than the dorsal striatum. Scale bar, 2.0 mm. 

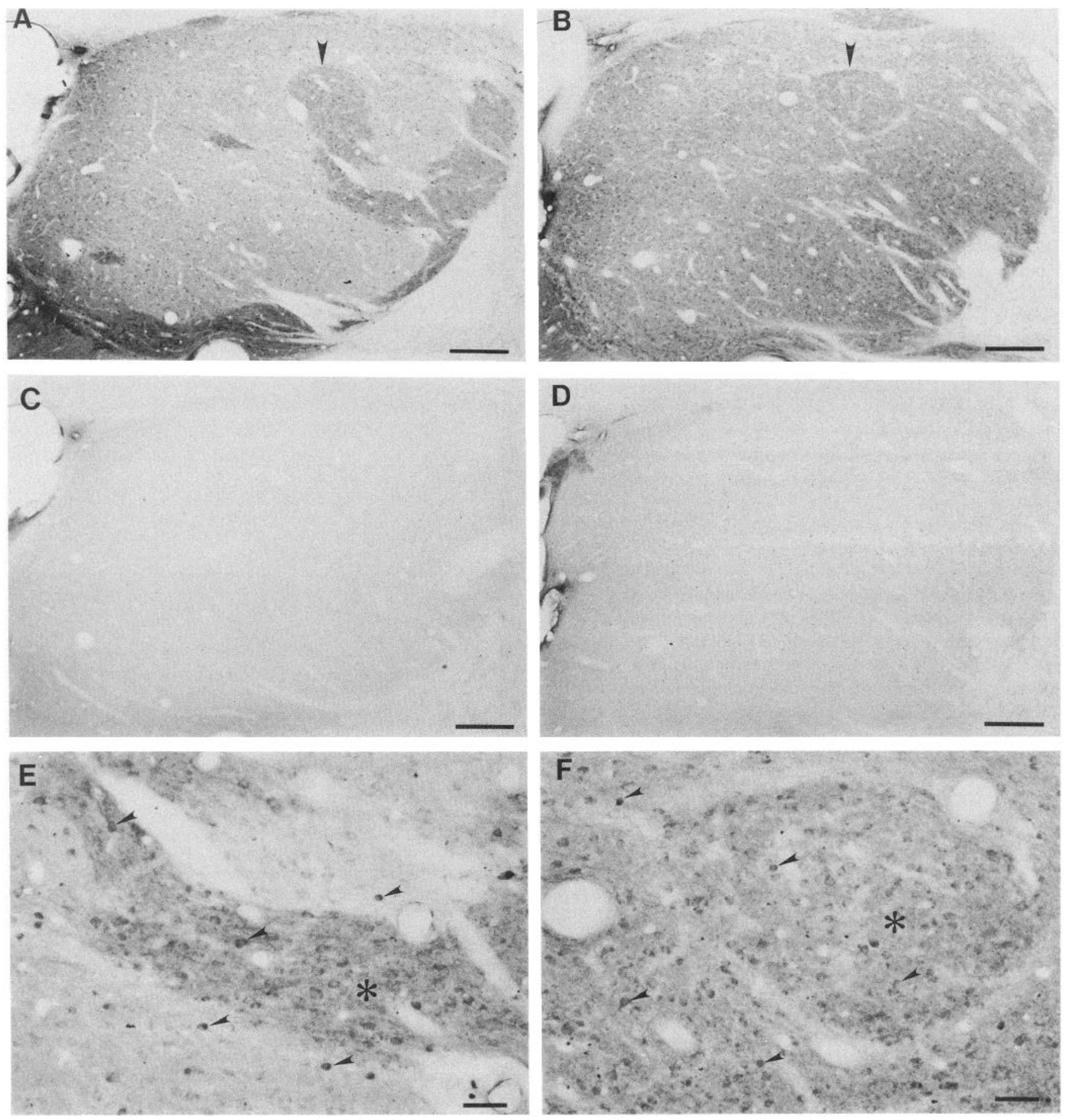

Figure 4. Photomicrographs of the body of the caudate nucleus illustrate regional and cellular distributions of GluR1 $(A, E)$ and GluR2/3 $(B, F)$ immunoreactivities as well as preadsorption controls $(C, D) . A$ and $B$, In striosomes (arrowheads), GluR1 $(A)$ is more enriched than GluR2/3 $(B)$ within the neuropil. $C$ and $D$, Preadsorption of GluR1 antibody against $30 \mu \mathrm{g}$ of synthetic GluR1 peptide abolished all immunocytochemical staining within the striatum $(C)$; preadsorption of GluR2/3 antibody against synthetic GluR2/3 peptide prevented staining within the striatum as well $(D) . E$, Numerous medium-sized, round/oval striatal neurons (arrowheads) are immunoreactive for GluR1, and the neuropil of striosomes is enriched in GluR1 immunoreactivity (asterisk). F, GluR2/3-immunoreactive striatal neurons are abundant (arrowheads), and the striosome compartment (asterisk) and surrounding matrix compartment have comparable amounts of GluR2/3 immunoreactivity within the neuropil. Scale bars: $A-D, 300 \mu \mathrm{m} ; E$ and $F, 50 \mu \mathrm{m}$.

striatum, and the immunocytochemical methods employed have been shown previously to optimize the visualization of antigens within the striatum (Martin et al., 1991b). In control preparations, the preadsorption of GluR antibodies with the specific synthetic C-terminal GluR peptides completely abolished all positive im- munocytochemical staining (Fig. 4, compare $A$ and $C, B$ and D).

Morphologically different populations of striatal neurons exhibited different patterns of GluR immunoreactivity (Table 1). Numerous, medium-sized, round perikarya expressed GluR1 
and GluR2/3 immunoreactivities; medium-sized, fusiform GluR1- and GluR2/3-immunoreactive neuronal cell bodies were present but less common (Figs. 4,5$)$. In plastic sections $(1 \mu \mathrm{m})$, GluR 1 and GluR2/3 immunoreactivities were clearly visualized within the cytoplasm of numerous medium-sized neuronal cell bodies (Fig. 5). Large $(20-60 \mu \mathrm{m})$ cholinergic striatal neurons did not show GluR1 and GluR2/3 immunoreactivities, but 50$60 \%$ of cholinergic neurons were immunoreactive for GluR4 (Fig. 6). A minor proportion of medium-sized, round-to-fusiform perikarya showed faint GluR4 immunoreactivity (Fig. 6A).

In thick $(40 \mu \mathrm{m})$ and semithin $(1 \mu \mathrm{m})$ sections, the striatal neuropil contained fine punctate and large spherical or globular GluR1 - and GluR2/3-immunoreactive structures (Figs. 5, 6), but GluR4-immunoreactive puncta were sparse (Fig. 6). U1trastructurally, these GluR1- and GluR2/3-immunoreactive structures within the striatal neuropil are dendritic shafts and dendritic spines (Fig. 5). There was no evidence for GluR immunoreactivities within presynaptic axonal terminals. Punctate GluR1 immunoreactivity was not distributed uniformly (Figs. $3,4,6,7)$. Within the dorsal striatum, striosome and matrix compartments were visualized in adjacent sections stained immunocytochemically for substance $\mathrm{P}$ and calbindin D-28, respectively. In this region, notably within the head of the caudate, GluR1 immunoreactivity was enriched in the neuropil of the striosomes relative to the matrix (Fig. 7). Ultrastructural analyses of striosomes sampled from Vibratome sections showed that GluR 1 immunoreactivity in the neuropil of striosomes was localized to postsynaptic elements. The numbers of GluR1positive neuronal cell bodies within striosomes and the surrounding matrix were roughly equivalent. GluR 1- and substance P-immunoreactive striosomes aligned with regions low in calbindin immunoreactivity (Fig. 7). In double-labeled sections, GluR1-immunoreactive somata within both striosomes and matrix colocalized with substance P (Fig. 6) and with leucineenkephalin; however, GluR 1/substance P-positive neuronal cell bodies were considerably more abundant in striosome than in matrix. Neuronal cell bodies immunoreactive for GluR4 and ChAT were numerous in the matrix, and few double-labeled neurons were found within striosomes. GluR1-immunoreactive postsynaptic processes were more enriched in the neuropil of the ventral striatum (i.e., the nucleus accumbens, olfactory tubercle, and fundus striati) than in the dorsal striatum (Figs. 3, $5,8)$. Within the nucleus accumbens, GluR 1 and GluR $2 / 3$ immunoreactivities were enriched uniformly throughout this region and did not show clear compartmental distributions in relation to substance $\mathrm{P}$ immunoreactivity (Fig. 8). However, in general, areas of the nucleus accumbens low in calbindin showed high levels of GluR1 (Fig. 8).

\section{Discussion}

The striatum receives convergent synaptic influences from widespread regions of cerebral cortex and thalamus (Rocha-Miranda, 1965; Kitai et al., 1976; Lidsky et al., 1976; Kocsis et al., 1977; Wilson, 1986). Corticostriatal and thalamostriatal projections, which form asymmetrical synapses principally on the dendritic spines of medium-sized spiny neurons (Kemp and Powell, 1971b; Frotscher et al., 1981; Somogyi et al., 1981), are excitatory and glutamatergic (Purpura and Malliani, 1971; Spencer, 1976; Kim et al., 1977; McGeer et al., 1977; Herrling and Hull, 1980; Fonnum et al., 1981; Young et al., 1983; Herrling, 1985; Walsh et al., 1989). Cortically evoked monosynaptic EPSPs in striatum may be mediated by ionotropic non-NMDA GluR (Herrling, 1985). The presence of striatal neurons expressing AMPA-pre-
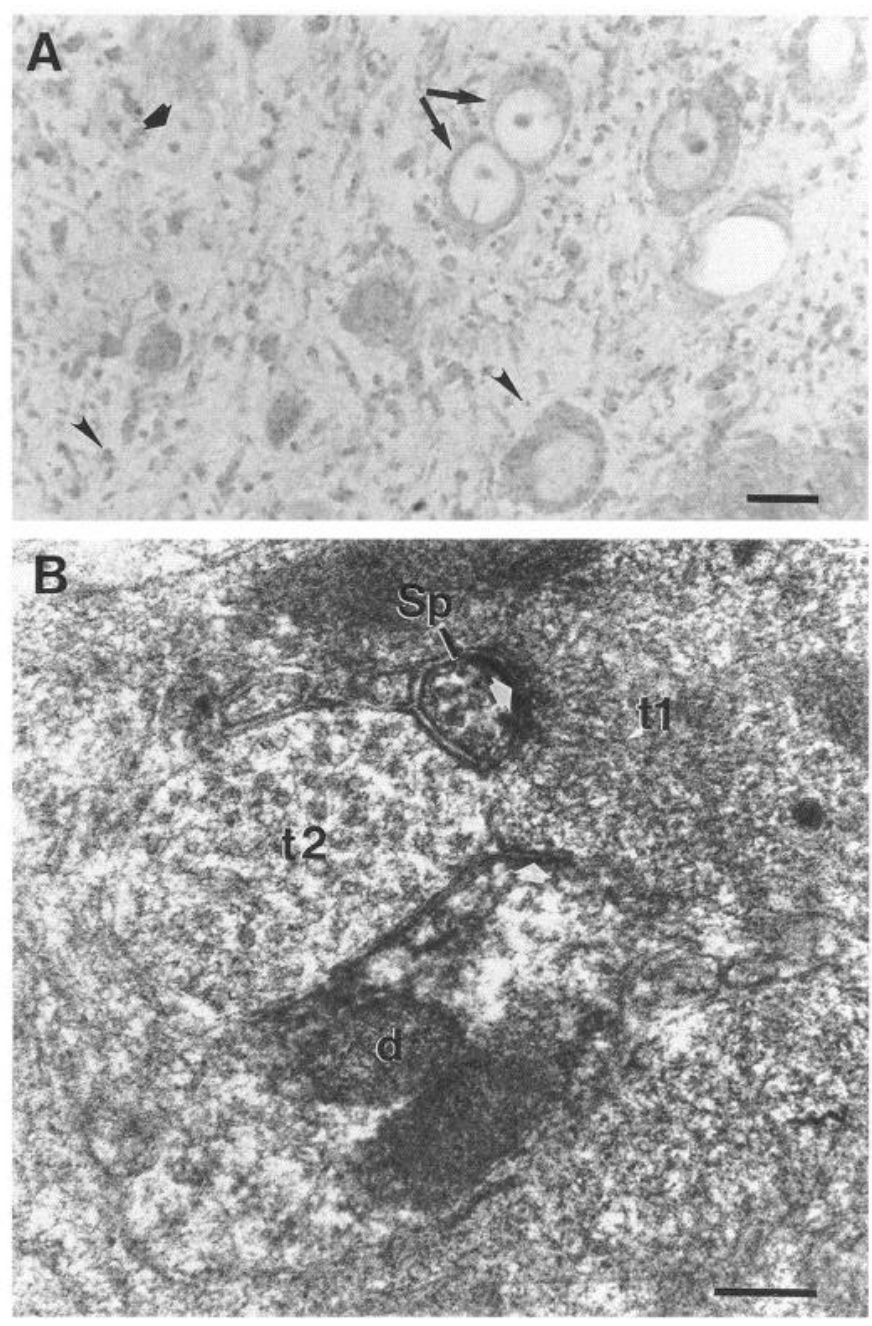

Figure 5. High-resolution light microscopic and ultrastructural localization of GluR1 immunoreactivity within monkey striatum. $A$, In 1 $\mu \mathrm{m}$ plastic sections, GluR1 immunoreactivity is visualized within medium-sized, round neuronal cell bodies (thin arrows). The neuropil is enriched in punctate and globular structures that are GluR1 immunoreactive (arrowheads), but at this level of resolution, their identity is uncertain. Within striatum, astrocytes are not immunoreactive for GluR 1 (thick arrow). B, Ultrastructurally, GluR1 immunoreactivity is found within dendritic spines $(S p)$ and in dendritic shafts $(d)$ within the striatal neuropil. Axonal terminals ( $t 1$ and $t 2)$ are interposed between spine and dendrite; $t 1$ forms asymmetrical synaptic junctions with both spine and dendrite (arrow). Scale bars: $A, 10 \mu \mathrm{m} ; B, 0.27 \mu \mathrm{m}$.

ferring GluR subunits and the localization of these GluR subunits within dendritic spines and dendritic shafts of striatal neurons are consistent with glutamatergic innervation of the striatum and the mediation of excitatory neurotransmission by ionotropic non-NMDA GluR. We have recently found that in rat striatum, GluR1, as well as GluR2 and/or GluR3 subunits of the AMPA receptor, is expressed postsynaptically in dendritic shafts and spines, but there was no evidence for the expression of AMPA receptors in presynaptic axonal terminals (Martin et al., 1992). Our present and previous (Martin et al., 1992) results indicate that medium-sized spiny and medium-sized and large aspiny striatal neurons receive glutamatergic inputs. Thus, AMPA GluR within the striatum may participate directly in the postsynaptic excitation of striatal output neurons and interneurons.

The present investigation shows that, in primates, different subtypes of striatal neurons express different AMPA receptor 

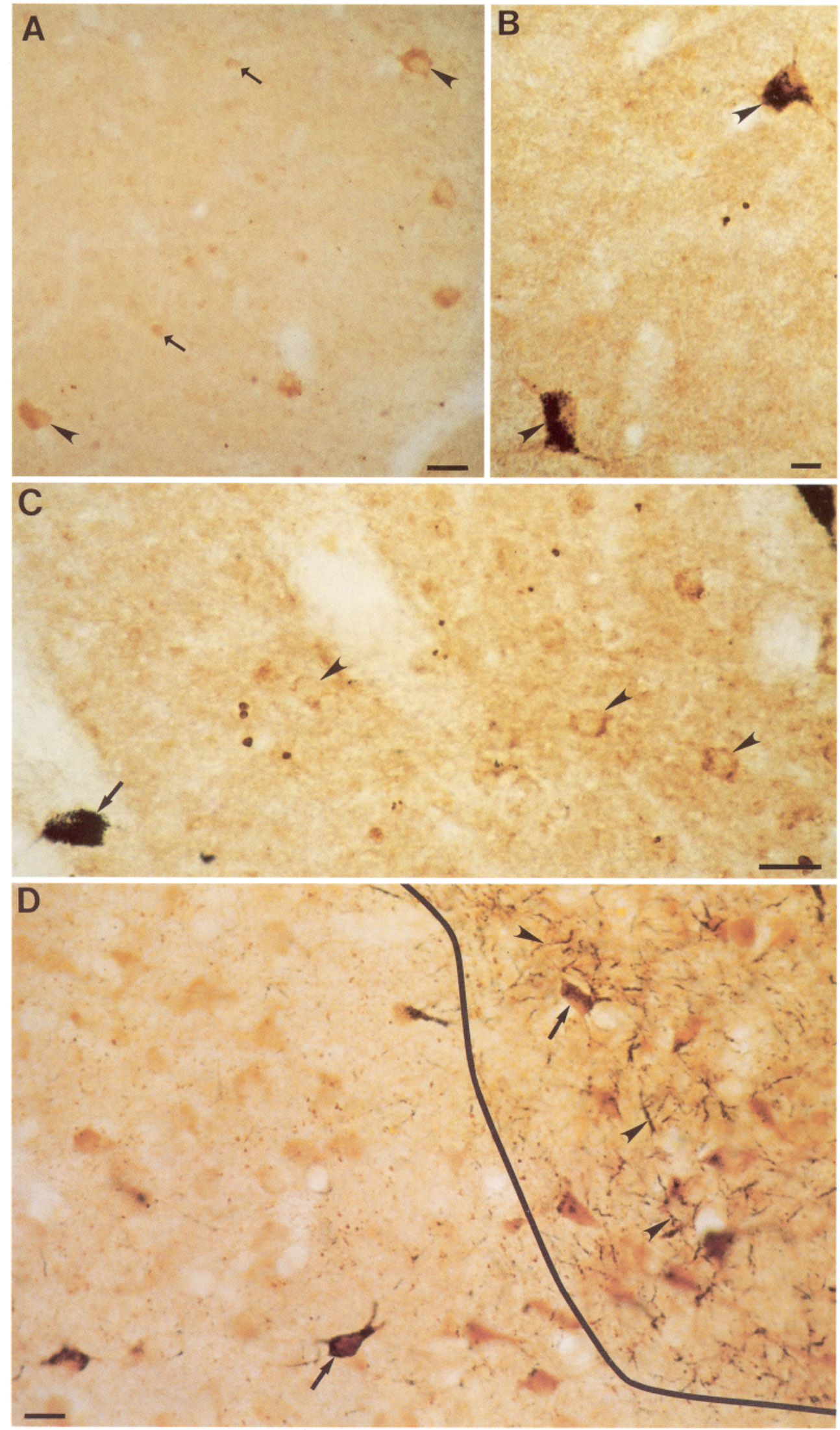

Figure 6. Cellular localization of GluR4, GluR2/3, and GluR1 immunoreactivities within monkey striatum and colocalization with neurotransmitter markers. A, GluR4 immunoreactivity is selectively enriched within a subset of large, round, striatal neurons (arrowheads). A minor subset of medium-sized neurons shows faint GluR4 immunoreactivity as well (arrows). $B$, Virtually all of the large GluR4-immunoreactive striatal neurons are also immunoreactive for ChAT (arrowheads). GluR4 immunoreactivity was visualized with diaminobenzidine (brown), and ChAT immunoreactivity was visualized with benzidine dihydrochloride (dark, granular reaction product). $C$, Striatal neurons that are GluR2/3 immunoreactive (arrowheads) are distinct from cholinergic neurons (arrow). $D$, Within striosomal and matrical compartments, subsets of substance P-immunoreactive neurons express GluR1 (arrows). GluR1-immunoreactive dendrites are enriched within striosomes (arrowheads). The solid black line delineates the approximate border between striosome (right) and matrix (left). Substance P immunoreactivity was visualized with diaminobenzidine (brown), and GluR 1 immunoreactivity was visualized with benzidine dihydrochloride (dark green, granular reaction product). Scale bars: $A, 40 \mu \mathrm{m} ; B, 12.5 \mu \mathrm{m} ; C 25 \mu \mathrm{m} ; D, 15$ $\mu \mathrm{m}$ 
Table 1. AMPA GluR in striatal neurons of monkey

\begin{tabular}{llll} 
& $\begin{array}{l}\text { Medium } \\
\text { spiny }\end{array}$ & $\begin{array}{l}\text { Medium } \\
\text { aspiny }\end{array}$ & $\begin{array}{l}\text { Large } \\
\text { aspiny }\end{array}$ \\
\hline GluR1 & + & + & - \\
GluR2/3 & + & + & - \\
GluR4 & - & + & + \\
\hline
\end{tabular}

Positive or negative immunocytochemical staining of different subsets of striatal neurons is indicated by + or - , respectively.

subunits (Table 1$)$. The majority ( $\sim 96 \%)$ of striatal neurons are medium sized, with perikarya measuring 10-20 $\mu \mathrm{m}$ in maximal diameter (Fox et al., 1971; Kemp and Powell, 1971a; DiFiglia et al., 1976; Pasik et al., 1976). Most medium-sized cells are spiny projection neurons that are peptidergic (i.e., using substance P, enkephalin, and/or dynorphin) and GABAergic (Aronin et al., 1984; Beckstead and Kersey, 1985; Penny et al., 1986; Anderson and Reiner, 1990; Besson et al., 1990). Only 1-2\% of striatal neurons have large $(20-60 \mu \mathrm{m})$ cell bodies; these cells are aspiny, cholinergic interneurons (DiFiglia, 1987). Spiny and aspiny neurons may also be distinguished by electrophysiological properties; aspiny neurons have larger input resistances, longer time constants, and relatively linear steady-state currentvoltage relationships compared to spiny neurons (Wilson et al., 1990). The present study demonstrates that most medium-sized striatal neurons express GluR1, as well as GluR2 and/or GluR3, but not GluR4, and that neurotransmitter markers for mediumsized spiny neurons colocalize with GluR1. In contrast, most large cholinergic neurons express GluR4 but not GluR1 and GluR2 or GluR3. Thus, it appears that the morphological, cytochemical, and electrophysiological diversities of striatal neurons are paralleled by differential cellular localizations of GluR subunits. We speculate that spiny, projection, striatal neurons, which exhibit large EPSPs in response to afferent stimulation (Bishop et al., 1982), express combinations of GluR subunits that form heterooligomeric ion channels, whereas large, aspiny, striatal interneurons may express GluR with different channel properties because of their possible homooligomeric composition. Because the subunit composition of AMPA-gated GluR determines their calcium permeability (Hollmann et al., 1991), subsets of striatal neurons may show differences in calciumdependent intracellular events following stimulation by glutamate. Support for this idea is derived from the observation that most medium-sized striatal projection neurons exhibit calbindin-D28 immunoreactivity (Gerfen et al., 1985; Martin et al., 1991a). This calcium binding protein is involved in mechanisms of intracellular sequestration of $\mathrm{Ca}^{+2}$ (Wasserman and Fullmer, 1983) and may, therefore, influence cellular responses to afferent synaptic excitation. Future studies of the colocalization of individual GluR subunits within individual striatal neurons, including specific distributions of GluR2 independent of GluR3, should provide clues to the subunit composition of AMPA receptors expressed by various subtypes of striatal neurons in vivo.

Glutamatergic corticostriatal terminal fields are organized within the framework of the striatal mosaic, and the areal and laminar origins of corticostriatal projections determine whether terminal fields align with striosome or matrix regions (Gerfen, 1989; Ragsdale and Graybiel, 1990). In several autoradiographic studies of rat and monkey, distributions of GluR subtypes within the dorsal striatum appear essentially uniform. Striosome and matrix patterns are not observed in ${ }^{3} \mathrm{H}$-ligand binding studies using kainic acid (Monaghan and Cotman, 1982; Unnerstall and Wamsley, 1983; Greenamyre et al., 1985a; Young et al., 1990), AMPA (Monaghan et al., 1984), quisqualate (Greenamyre et al., 1985a), L-glutamate (Greenamyre et al., 1985a), and NMDA (Greenamyre et al., 1985b; Monaghan and Cotman, 1985; Young et al., 1990). However, this immunocytochemical study demonstrates that different AMPA receptor subunits are selectively enriched within striosome (i.e., GluR1) and matrix (i.e., GluR4) compartments of the primate striatum.

The cellular localization of GluR subtypes within the striatum may have a bearing on the functional significance of striosome and matrix compartments. For example, relative to matrix, striosomes may be more densely innervated by glutamatergic synapses. It appears that non-NMDA ionotropic GluR are expressed differentially by striatonigral neurons that reside in striosomes and striatopallidal neurons that reside in the matrix; thus, glutamate may have differential physiological effects on these two subpopulations of striatal output neurons. Moreover, AMPA receptors that have a specific subunit composition may predominate in striosomes; NMDA receptors may predominate in matrix, as suggested by studies showing that the regulation of dopamine release through NMDA receptors is more pronounced in the matrix (Krebs et al., 1991). Alternatively, if both AMPA and NMDA receptors are enriched within striosomes, then perhaps striosomes function in activity-dependent synaptic plasticity, a phenomenon that, within corticostriatal circuits, may participate in habit formation (i.e., procedural memory or
Figure 7. Comparison between the striosome/matrix patterns of GluR $1(A)$, calbindin $(B)$, and substance $\mathrm{P}(C)$ immunoreactivities in near-adjacent sections through the head of the caudate nucleus. Striosomes exhibiting dense GluR1 immunoreactivity (arrowheads in $A$ ) align with regions containing low calbindin immunoreactivity (arrowheads in $B$ ) and regions enriched in substance $\mathrm{P}$ immunoreactivity (arrowheads in $C$ ). Scale bar, $715 \mu \mathrm{m}$.
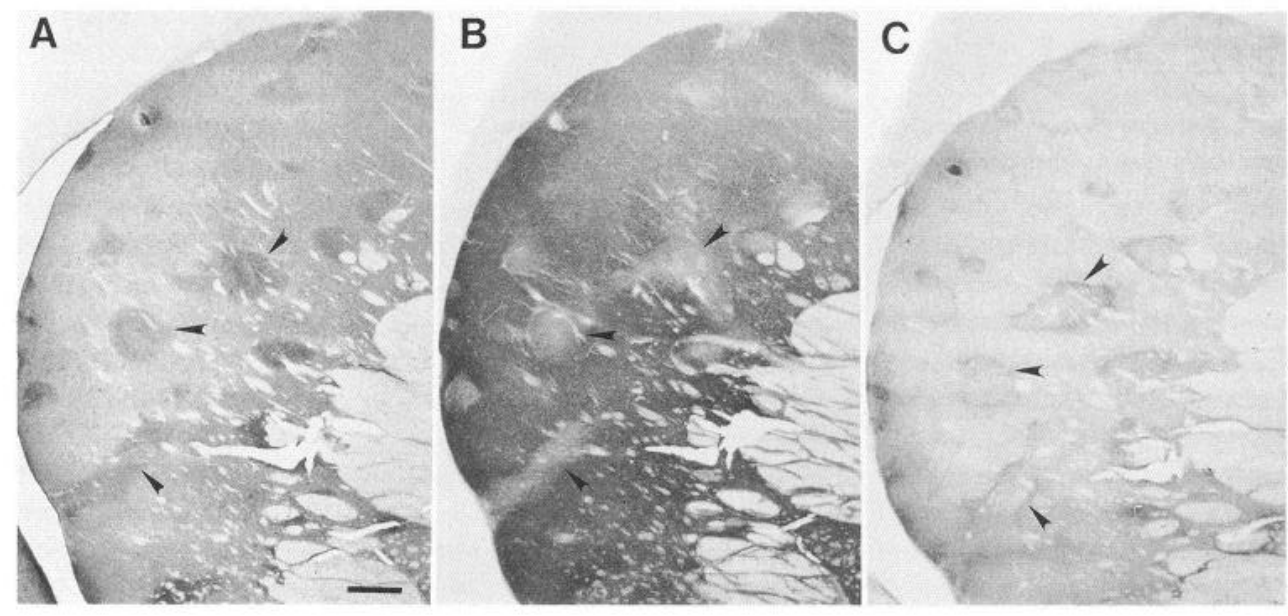

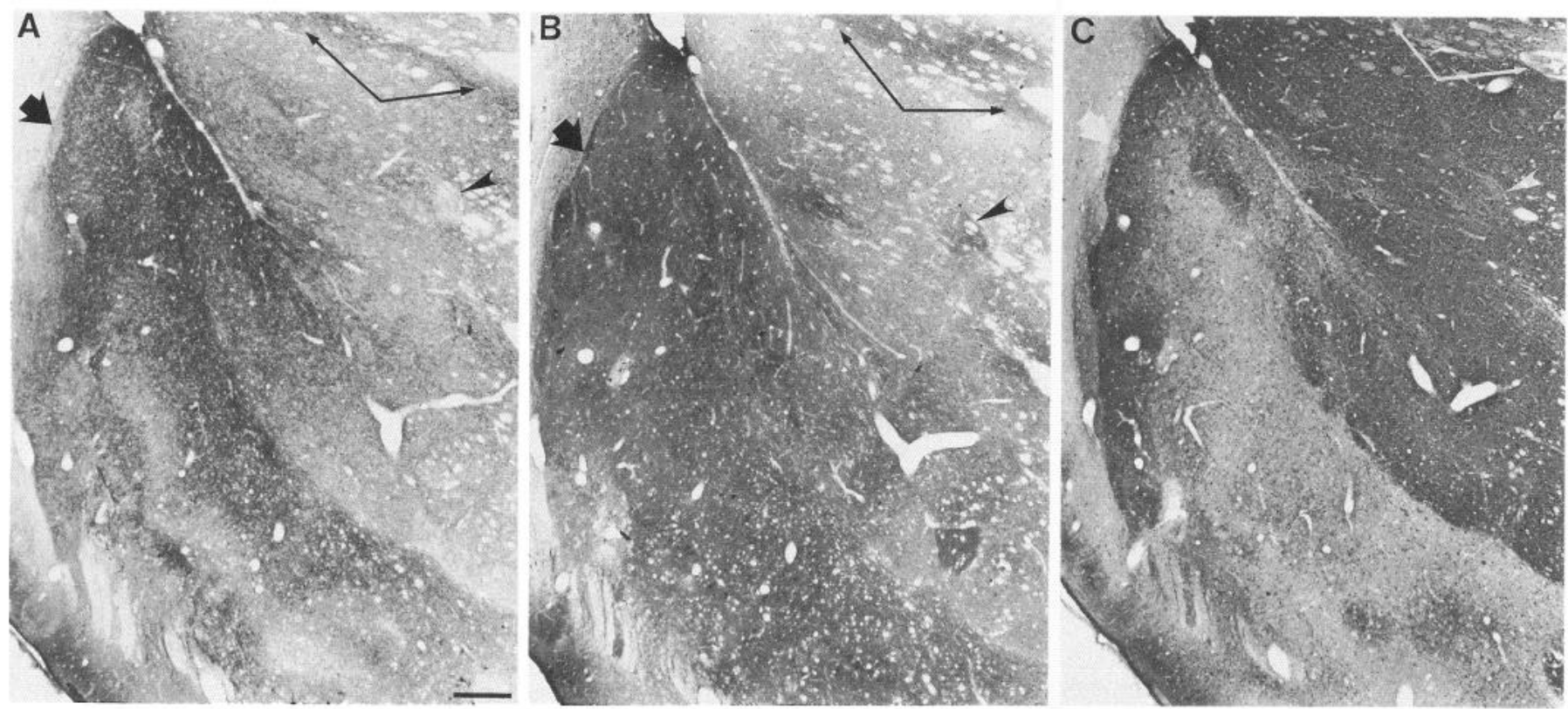

Figure 8. Comparison between the distributions of substance $\mathrm{P}(A)$, GluR1 $(B)$, and calbindin $(C)$ immunoreactivities in near-adjacent sections through the nucleus accumbens. GluR 1 does not show obvious compartmental distributions in the nucleus accumbens when compared to substance $P$. In the ventromedial caudate nucleus, some striosomes enriched in GluR 1 (thin arrows in $B$ ) are rimmed or capped by substance P immunoreactivity (thin arrows in $A$ ) and show lower calbindin relative to matrix (thin arrows in $C$ ). Other striosomes in the ventromedial caudate nucleus show relatively low levels of substance P and calbindin and are enriched in GluR1 (arrowheads in $A-C$ ). The distributions of GluR1 and calbindin in the nucleus accumbens tend to be inversely related (thick arrows in $B$ and $C$ ), and some foci low in substance $\mathrm{P}($ thick arrow in $A$ ) show high levels of GluR1. Scale bar, $377 \mu \mathrm{m}$.

conditioned behaviors) (Bachevalier and Mishkin, 1984; Mishkin et al., 1984). The possibility for a spatial overlap of AMPA receptors and inputs from medial frontal cortex and basolateral amygdala within striosomes (Gerfen, 1984; Donoghue and Herkenham, 1986; Ragsdale and Graybiel, 1988) is consistent with this idea. The simultaneous activation of glutamatergic cortical and amygdalar inputs to striosomal neurons may activate AMPA receptors that provide the depolarization needed for release of the voltage-dependent $\mathrm{Mg}^{2+}$ block of NMDA receptor channels, $\mathrm{Ca}^{2+}$ influx, and subsequent long-term changes in synaptic function and in activity-dependent regulation of neurotransmitters.

An important relationship may exist between the cellular expression of GluR subtypes and mechanisms that regulate the expression of neurotransmitters within striatal neurons. Striatal afferents participate in the steady-state regulation of peptide expression in medium-sized spiny striatal neurons. For example, ablation of corticostriatal projections reduces preprotachykinin and preproenkephalin mRNA in neurons of rodent striatum (Uhl et al., 1988; Somers and Beckstead, 1990). Synaptic activity and membrane depolarization regulate neural gene expression (Hendry et al., 1988; Lowenstein et al., 1991), possibly through a calcium-dependent mechanism that may involve calmodulin (Van Nguyen et al., 1990), and immunocytochemical studies show that striatal neurons are enriched in calmodulin (Wood et al., 1980). Thus, glutamatergic neurotransmission may directly regulate, in an activity-dependent manner, levels of neurotransmitter expression within subsets of striatal output and intrinsic neurons. Some support for this idea is derived from the morphological observation that the GluR 1 subunit of the AMPA receptor is expressed by substance P- and enkephalin-containing neurons within striatal striosomes and matrix. The relative enrichment of GluR 1 at postsynaptic sites within striosomes may possibly foreshadow a more dominant glutamatergic regulatory control of neuropeptide expression in strio- somal neurons compared to matrical neurons. Although the activation of molecular subtypes of GluR may provide a potential postsynaptic site for the glutamatergic regulation of striatal neurotransmitters, there is presently no direct evidence to support such a mechanism. However, subtypes of dopamine receptors regulate the relative levels of expression of opiate and tachykinin peptides in subpopulations of striatal neurons (Gerfen et al., 1990); similar mechanisms mediated by GluR subtypes may be operative within the striatum.

Complex neurotransmitter receptor-mediated events influence striatal neurons as well as afferent terminals. For example, excitatory postsynaptic responses in the nucleus accumbens, which show a greater enrichment of GluR1 as well as GluR2 and/or GluR3 subunits than does the dorsal striatum, are evoked by hippocampal and amygdalar stimulation. These responses are attenuated by dopamine and by mesolimbic dopaminergic inputs (Yang and Mogenson, 1984; Yim and Mogenson, 1986). Moreover, the release of dopamine from nigrostriatal nerve terminals is believed to be regulated by corticostriatal afferents, because the application of glutamate increases the release of dopamine in the striatum in vivo (Chéramy et al., 1986) and in vitro (Giorguieff et al., 1977; Roberts and Anderson, 1979); this effect may be mediated by non-NMDA GluR (Imperato et al., 1990) and NMDA GluR (Ransom and Deschenes, 1989; Krebs et al., 1991). However, the precise mechanisms by which glutamate and dopamine interact are not clear. In striatal slices, a direct presynaptic regulation mediated by GluR located on dopaminergic terminals has been suggested (Chéramy et al., 1986; Krebs et al., 1991), but we found no ultrastructural evidence for a presynaptic localization of AMPA receptors. Our anatomical observations and the pharmacological findings of others (Moghaddam et al., 1990) suggest that indirect regulation mediated by GluR on nondopaminergic elements (e.g., cholinergic neurons) is possible. Detailed subcellular analyses of the distri- 
butions of other GluR subtypes (e.g., NMDA receptors and high-affinity KA receptors) and dopamine receptor subtypes will help to clarify the precise mechanisms that mediate glutamatergic and dopaminergic interactions within the striatum. Recently, molecular cloning studies have characterized subunits for KA-preferring GluR (i.e., GluR5, GluR6, and KA1) (Bettler et al., 1990; Egebjerg et al., 1991; Werner et al., 1991), the NMDA receptor (Moriyoshi et al., 1991), and a family of metabotropic GluR (mGluR1-mGluR4) (Houamed et al., 1991; Masu et al., 1991; Tanabe et al., 1992). Markers for the phosphoinositide second-messenger system are enriched within the neuropil of striosomes in the primate caudate nucleus (Fotuhi et al., 1991); thus, ionotropic and phosphoinositide-linked metabotropic GluR may coexist within subsets of striatal neurons. Further studies using specific antibodies to the different GluR subtypes will provide new insights into the roles of various GluR in the physiological functions of different populations of striatal neurons.

\section{References}

Anderson KD, Reiner A (1990) Extensive co-occurrence of substance $P$ and dynorphin in striatal projection neurons: an evolutionarily conserved feature of basal ganglia organization. J Comp Neurol 295: 339-369.

Aronin N, DiFiglia M, Graveland GA, Schwartz WJ, Wu J-Y (1984) Localization of immunoreactive enkephalins in GABA synthesizing neurons of the rat neostriatum. Brain Res 300:376-380.

Atweh SF, Kuhar MJ (1977) Autoradiographic localization of opiate receptors in rat brain. III. The telencephalon. Brain Res 134:393405 .

Bachevalier J, Mishkin M (1984) An early and a late developing system for learning and retention in infant monkeys. Behav Neurosci 98: 770-778.

Beach TG, McGeer EG (1984) The distribution of substance $P$ in the primate basal ganglia: an immunohistochemical study of baboon and human brain. Neuroscience 13:29-52.

Beckstead RM, Kersey KS (1985) Immunohistochemical demonstration of differential substance P-, met-enkephalin-, and glutamic-aciddecarboxylase-containing cell body and axon distributions in the corpus striatum of the cat. J Comp Neurol 232:481-498.

Besson MJ, Graybiel AM, Nastuk MA (1988) [ $\left.{ }^{3} \mathrm{H}\right] \mathrm{SCH} 23390$ binding to $D_{1}$ dopamine receptors in the basal ganglia of the cat and primate: delineation of striosomal compartments and pallidal and nigral subdivisions. Neuroscience 26:101-119.

Besson MJ, Graybiel AM, Quinn B (1990) Co-expression of neuropeptides in the cat's striatum: an immunohistochemical study of substance $P$, dynorphin B and enkephalin. Neuroscience 39:33-58.

Bettler B, Boulter J, Hermans-Borgmeyer I, O'Shea-Greenfield A, Deneris ES, Moll C, Borgmeyer U, Hollmann M, Heinemann S (1990) Cloning of a novel glutamate receptor subunit, GluR5: expression in the nervous system during development. Neuron 5:583-595.

Bishop GA, Chang HT, Kitai ST (1982) Morphological and physiological properties of neostriatal neurons: an intracellular horseradish peroxidase study in the rat. Neuroscience 7:179-191.

Blackstone CD, Moss SJ, Martin LJ, Levey AI, Price DL, Huganir RL (1992a) Biochemical characterization and localization of a non- $N$ methyl-D-aspartate glutamate receptor in rat brain. J Neurochem 58 : $1118-1126$.

Blackstone CD, Levey AI, Martin LJ, Price DL, Huganir RL (1992b) Immunological detection of glutamate receptor subtypes in human central nervous systcm. Ann Ncurol 31:680-683.

Boulter J, Hollmann M, O'Shea-Greenfield A, Hartley M, Deneris E, Maron C, Heinemann S (1990) Molecular cloning and functional expression of glutamate receptor subunit genes. Science 249:10331037.

Cha J-HJ, Greenamyre JT, Nielsøn EO, Penney JB, Young AB (1988) Properties of quisqualate-sensitive $\mathbf{L}-\left[{ }^{3} \mathrm{H}\right]$ glutamate binding sites in rat brain as determined by quantitative autoradiography. J Neurochem 51:469-478.

Chéramy A, Romo R, Godeheu G, Baruch P, Glowinski J (1986) In vivo presynaptic control of dopamine release in the cat caudate nu- cleus. II. Facilitatory or inhibitory influence of L-glutamate. Neuroscience 19:1081-1090.

DiFiglia M (1987) Synaptic organization of cholinergic neurons in the monkey neostriatum. J Comp Neurol 255:245-258.

DiFiglia M, Pasik P, Pasik T (1976) A Golgi study of neuronal types in the neostriatum of monkeys. Brain Res 114:245-256.

Donoghue JP, Herkenham M (1986) Neostriatal projections from individual cortical fields conform to histochemically distinct striatal compartments in the rat. Brain Res 365:397-403.

Egebjerg J, Bettler B, Hermans-Borgmeyer I, Heinemann S (1991) Cloning of a cDNA for a glutamate receptor subunit activated by kainate but not AMPA. Naturc 351:745-748.

Fonnum F, Storm-Mathisen J, Divac I (1981) Biochemical evidence for glutamate as neurotransmitter in corticostriatal and corticothalamic fibres in rat brain. Neuroscience 6:863-873.

Fotuhi M, Dawson TM, Sharp AH, Martin LJ, Graybiel AM, Snyder SH (1991) The phosphoinositide second messenger system is enriched in striosomes of the primate striatum. Soc Neurosci Abstr 17: 854.

Fox CA, Andrade AN, Hillman DE, Schwyn RC (1971) The spiny neurons in the primate striatum: a Golgi and electron microscopic study. J Hirnforsch 13:181-201.

Frotscher M, Rinne U, Hassler R, Wagner A (1981) Termination of cortical afferents on identified neurons in the caudate nucleus of the cat. Exp Brain Res 41:329-337.

Gallo V, Upson LM, Haycs WP, Vyklicky L Jr, Wintcrs CA, Buonanno A (1992) Molecular cloning and developmental analysis of a new glutamate receptor subunit isoform in cerebellum. J Neurosci 12: 1010-1023.

Gasic GP, Heinemann S (1991) Receptors coupled to ionic channels: the glutamate receptor family. Curr Opin Neurobiol 1:20-26.

Gerfen CR (1984) The neostriatal mosaic: compartmentalization of corticostriatal input and striatonigral output systems. Nature 311: $461-464$.

Gerfen CR (1985) The neostriatal mosaic. I. Compartmental organization of projections from the striatum to the substantia nigra in the rat. J Comp Neurol 236:454-476.

Gerfen CR (1989) The neostriatal mosaic: striatal patch-matrix organization is related to cortical lamination. Science 246:385-388.

Gerfen CR, Baimbridge KG, Miller JJ (1985) The neostriatal mosaic: compartmental distribution of calcium-binding protein and parvalbumin in the basal ganglia of the rat and monkey. Proc Natl Acad Sci USA 82:8780-8784.

Gerfen CR, Herkenham M, Thibault J (1987) The neostriatal mosaic. II. Patch- and matrix-directed mesostriatal dopaminergic and nondopaminergic systems. J Neurosci 7:3915-3934.

Gerfen CR, Engber TM, Mahan LC, Susel Z, Chase TN, Monsma FJ Jr, Sibley DR (1990) $D_{1}$ and $D_{2}$ dopamine receptor-regulated gene expression of striatonigral and striatopallidal neurons. Science 250: $1429-1432$

Giménez-Amaya J-M, Graybiel AM (1991) Modular organization of projection neurons in the matrix compartment of the primate striatum. J Neurosci 11:779-791.

Giorguieff MF, Kemcl ML, Glowinski J (1977) Presynaptic effect of L-glutamic acid on the release of dopamine in rat striatal slices. Neurosci Lett 6:73-77.

Goldman PS, Nauta WJ (1977) An intricately patterned prefrontocaudate projection in the rhesus monkey. J Comp Neurol 171:369386.

Goldman-Rakic PS (1982) Cytoarchitectonic heterogeneity of the primate neostriatum: subdivision into island and matrix cellular compartments. J Comp Neurol 205:398-413.

Graybiel AM (1990) Neurotransmitters and neuromodulators in the basal ganglia. Trends Neurosci 13:244-254.

Graybiel AM, Ragsdale CW Jr (1978) Histochemically distinct compartments in the striatum of human, monkey, and cat demonstrated by acetylthiocholinesterase staining. Proc Natl Acad Sci USA 75: $5723-5726$.

Graybiel AM, Ragsdale CW Jr (1983) Biochemical anatomy of the striatum. In: Chemical neuroanatomy (Emson PC, ed), pp 427-504. New York: Raven.

Graybiel AM, Baughman RW, Eckenstein F (1986) Cholinergic neuropil of the striatum observes striosomal boundaries. Nature 323 : 625-627.

Graybiel AM, Hirsch EC, Agid YA (1987) Differences in tyrosine 
hydroxylase-like immunoreactivity characterize the mesostriatal innervation of striosomes and extrastriosomal matrix at maturity. Proc Natl Acad Sci USA 84:303-307.

Greenamyre JT, Olson JMM, Penney JB Jr, Young AB (1985a) Autoradiographic characterization of $N$-methyl-D-aspartate-, quisqualate- and kainate-sensitive glutamate binding sites. J Pharmacol Exp Ther 233:254-263.

Greenamyre JT, Penney JB, Young AB, D'Amato CJ, Hicks SP, Shoulson I (1985b) Alterations in L-glutamate binding in Alzheimer's and Huntington's diseases. Science 227:1496-1499.

Haber S, Elde R (1982) The distribution of enkephalin immunoreactive fibers and terminals in the monkey central nervous system: an immunohistochemical study. Neuroscience 7:1049-1095.

Haber SN, Watson SJ (1985) The comparative distribution of enkephalin, dynorphin and substance $P$ in the human globus pallidus and basal forebrain. Neuroscience 14:1011-1024.

Hamel E, Beaudet A (1984) Localization of opioid binding sites in rat brain by electron microscopic radioautography. J Electron Microsc Tech 1:317-329.

Hendry SHC, Jones EG, Burstein N (1988) Activity-dependent regulation of tachykinin-like immunoreactivity in neurons of monkey visual cortex. J Neurosci 8:1225-1238.

Herkenham M, Pert CB (1981) Mosaic distribution of opiate receptors, parafasicular projections and acetylcholinesterase in rat striatum. $\mathrm{Na}$ ture 291:415-418.

Herrling PL (1985) Pharmacology of the corticocaudate excitatory postsynaptic potential in the cat: evidence for its mediation by quisqualate- or kainate-receptors. Neuroscience 14:417-426.

Herrling PL, Hull CD (1980) Iontophoretically applied dopamine depolarizes and hyperpolarizes the membrane of cat caudate neurons. Brain Res 192:441-462.

Hollmann M, O'Shea-Greenfield A, Rogers SW, Heinemann S (1989) Cloning by functional expression of a member of the glutamate receptor family. Nature 342:643-648.

Hollmann M, Hartley M, Heinemann S (1991) $\mathrm{Ca}^{2+}$ permeability of KA-AMPA-gated glutamate receptor channels depends on subunit composition. Science 252:851-852.

Houamed KM, Kuijper JL, Gilbert TL, Haldeman BA, O'Hara PJ, Mulvihill ER, Almers W, Hagen FS (1991) Cloning, expression, and gene structure of a $\mathbf{G}$ protein-coupled glutamate receptor from rat brain. Science 252:1318-1321.

Imperato A, Honore T, Jensen LH (1990) Dopamine release in the nucleus caudatus and in the nucleus accumbens is under glutamatergic control through non-NMDA receptors: a study in freely-moving rats. Brain Res 530:223-228.

Joyce JN, Sapp DW, Marshall JF (1986) Human striatal dopamine receptors are organized in compartments. Proc Natl Acad Sci USA 83:8002-8006.

Kawaguchi Y, Wilson CJ, Emson PC (1990) Projection subtypes of rat neostriatal matrix cells revealed by intracellular injection of biocytin. J Neurosci 10:3421-3438.

Keinänen K, Wisden W, Sommer B, Werner P, Herb A, Verdoorn TA, Sakmann B, Seeburg PH (1990) A family of AMPA-selective glutamate receptors. Science 249:556-560.

Kemp JM, Powell TPS (1971a) The structure of the caudate nucleus of the cat: light and electron microscopy. Philos Trans R Soc Lond 262:383-401.

Kemp JM, Powell TPS (1971b) The site of termination of afferent fibres in the caudate nucleus. Philos Trans R Soc Lond 262:413-427.

Kim J-S, Hassler R, Haug P, Paik K-S (1977) Effect of frontal cortex ablation on striatal glutamic acid level in rat. Brain Res 132:370374.

Kitai ST, Kocsis JD, Wood J (1976) Origin and characteristics of the cortico-caudate afferents: an anatomical and electrophysiological study. Brain Res 118:137-141.

Kocsis JD, Sugimori M, Kitai ST (1977) Convergence of excitatory synaptic inputs to caudate spiny neurons. Brain Res 124:403-413.

Krebs M-O, Trovero F, Desban M, Gauchy C, Glowinski J, Kemel M-L (1991) Distinct presynaptic regulation of dopamine release through NMDA receptors in striosome- and matrix-enriched areas of the rat striatum. J Neurosci 1 1:1256-1262.

Langer LF, Graybiel AM (1989) Distinct nigrostriatal projection systems innervate striosomes and matrix in the primate striatum. Brain Res 498:344-350.

Levey AI, Bolam JP, Rye DB, Hallanger AE, Demuth RM, Mesulam
M-M, Wainer BH (1986) A light and electron microscopic procedure for sequential double antigen localization using diaminobenzidine and benzidine dihydrochloride. J Histochem Cytochem 34:1449-1457.

Lidsky TI, Buchwald NA, Hull CD, Levine MS (1976) A neurophysiological analysis of the development of cortico-caudate connections in the cat. Exp Neurol 50:283-292.

Lowenstein DH, Miles MF, Hatam F, McCabe T (1991) Up regulation of calbindin-D28K mRNA in the rat hippocampus following focal stimulation of the perforant path. Neuron 6:627-633.

Martin LJ, Hadfield MG, Dellovade TL, Price DL (1991a) The striatal mosaic in primates: patterns of neuropeptide immunoreactivity differentiate the ventral striatum from the dorsal striatum. Neuroscience 43:397-417.

Martin LJ, Spicer DM, Lewis MH, Gluck JP, Cork LC (1991b) Social deprivation of infant rhesus monkeys alters the chemoarchitecture of the brain. I. Subcortical regions. J Neurosci 11:3344-3358.

Martin LJ, Blackstone CD, Huganir RL, Price DL (1992) Glutamate receptors show species differences in the striatum. J Neuropathol Exp Neurol 51:352.

Martin LJ, Blackstone CD, Levey AI, Huganir RL, Price DL (in press) AMPA glutamate receptor subunits are differentially distributed in rat brain. Neuroscience, in press.

Masu M, Tanabe Y, Tsuchida K, Shigemoto R, Nakanishi S (1991) Sequence and expression of a metabotropic glutamate receptor. Nature 349:760-765.

McGeer PL, McGeer EG, Scherer U, Singh K (1977) A glutamate corticostriatal path? Brain Res 128:369-373.

Mishkin M, Malamut B, Bachevalier J (1984) Memories and habits: two neural systems. In: Neurobiology of learning and memory (Lynch G, McGaugh JL, Weinberger NM, eds), pp 65-77. New York: Guilford.

Moghaddam B, Gruen RJ, Roth RII, Bunney BS, Adams RN (1990) Effect of L-glutamate on the release of striatal dopamine: in vivo dialysis and electrochemical studies. Brain Res 518:55-60.

Monaghan DT, Cotman CW (1982) The distribution of $\left({ }^{3} \mathrm{H}\right)$ kainic acid binding sites in rat CNS as determined by autoradiography. Brain Res 252:91-100.

Monaghan DT, Yao D, Cotman CW (1984) Distribution of [ $\left.{ }^{3} \mathrm{H}\right]$ AMPA binding sites in rat brain as determined by quantitative autoradiography. Brain Res 324:160-164.

Monaghan DT, Bridges RJ, Cotman CW (1989) The excitatory amino acid receptors: their classes, pharmacology, and distinct properties in the function of the central nervous system. Annu Rev Pharmacol Toxicol 29:365-402.

Moriyoshi K, Masu M, Ishii T, Shigemoto R, Mizuno N, Nakanishi S (1991) Molecular cloning and characterization of the rat NMDA receptor. Nature 354:31-37.

Nastuk MA, Graybiel AM (1988) Autoradiographic localization and biochemical characteristics of M1 and M2 muscarinic binding sites in the striatum of the cat, monkey, and human. J Neurosci 8:10521062.

Pasik P, Pasik T, DiFiglia M (1976) Quantitative aspects of neuronal organization in the neostriatum of the macaque monkey. In: Research publications of the Association for Research in Nervous and Mental Disease, Vol 55, The basal ganglia (Yahr MD, ed), pp 570-589. New York: Raven.

Penny GR, Afsharpour S, Kitai ST (1986) The glutamate decarboxylase-, leucine enkephalin-, methionine enkephalin- and substance P-immunoreactive neurons in the neostriatum of the rat and cat: evidence for partial population overlap. Neuroscience 17:1011-1045.

Purpura DP, Malliani A (1967) Intracellular studies of the corpus striatum. I. Synaptic potentials and discharge characteristics of caudate neurons activated by thalamic stimulation. Brain Res 6:325340.

Ragsdale CW Jr, Graybiel AM (1981) The fronto-striatal projection in the cat and monkey and its relationship to inhomogeneities established by acetylcholinesterase histochemistry. Brain Res 208:259_ 266.

Ragsdale CW Jr, Graybiel AM (1988) Fibers from the basolateral nucleus of the amygdala selectively innervate striosomes in the caudate nucleus of the cat. J Comp Neurol 269:506-522.

Ragsdale CW Jr, Graybiel AM (1990) A simple ordering of neocortical areas established by the compartmental organization of their striatal projections. Proc Natl Acad Sci USA 87:6196-6199.

Ransom RW, Deschenes NL (1989) Glycine modulation of NMDA- 
evoked release of $\left[{ }^{3} \mathrm{H}\right]$ acetylcholine and $\left({ }^{3} \mathrm{H}\right)$ dopamine from rat striatal slices. Neurosci Lett 96:323-328.

Roberts PJ, Anderson SD (1979) Stimulatory effect of L-glutamate and related amino acids on $\left[{ }^{3} \mathrm{H}\right]$ dopamine release from rat striatum: an in vitro model for glutamate actions. J Neurochem 32:1539-1545.

Rocha-Miranda CE (1965) Single unit analysis of cortex-caudate connections. Electroencephalogr Clin Neurophysiol 19:237-247.

Russchen FT, Bakst I, Amaral DG, Price JF (1985) The amygdalostriatal projections in the monkey. An anterograde tracing study. Brain Res 329:241-257.

Selemon LD, Goldman-Rakic PS (1985) Longitudinal topography and interdigitation of corticostriatal projections in the rhesus monkey. $J$ Neurosci 5:776-794.

Somers DL, Beckstead RM (1990) Striatal preprotachykinin and preproenkephalin mRNA levels and the levels of nigral substance $P$ and pallidal Met ${ }^{5}$-enkephalin depend on corticostriatal axons that use the excitatory amino acid neurotransmitters aspartate and glutamate: quantitative radioimmunocytochemical and in situ hybridization evidence. Mol Brain Res 8:143-158.

Somogyi P, Bolam JP, Smith AD (1981) Monosynaptic cortical input and local axon collaterals of identified striatonigral neurons. A light and electron microscopic study using the Golgi-peroxidase transportdegeneration procedure. J Comp Neurol 195:567-584.

Spencer HJ (1976) Antagonism of cortical excitation of striatal neurons by glutamatic acid diethyl ester: evidence for glutamic acid as an excitatory transmitter in the rat striatum. Brain Res 102:91-101.

Tanabe Y, Masu M, Ishii T, Shigemoto R, Nakanishi S (1992) A family of metabotropic glutamate receptors. Neuron 8:169-179.

Uhl GR, Navia B, Douglas J (1988) Differential expression of preproenkephalin and preprodynorphin mRNAs in striatal neurons: high levels of preproenkephalin expression depend on cerebral cortical afferents. J Neurosci 8:4755-4764.

Unnerstall JR, Wamsley JK (1983) Autoradiographic localization of high-affinity $\left[{ }^{3} \mathrm{H}\right]$ kainic acid binding sites in the rat forebrain. Eur $\mathrm{J}$ Pharmacol 86:361-371.

Van Nguyen T, Kobierski L, Comb M, Hyman SE (1990) The effect of depolarization on expression of the human proenkephalin gene is synergistic with cAMP and dependent upon a cAMP-inducible enhancer. J Neurosci 10:2825-2833.
Walsh JP, IIull CD, Levine MS, Buchwald NA (1989) Kynurenic acid antagonizes the excitatory postsynaptic potential elicited in neostriatal neurons in the in vitro slice of the rat. Brain Res 480:290-293.

Wasserman RH, Fullmer CS (1983) Calcium transport proteins, calcium absorption, and vitamin D. Annu Rev Physiol 45:375-390.

Watkins JC, Krogsgaard-Larsen P, Honoré T (1990) Structure-activity relationships in the development of excitatory amino acid receptor agonists and competitive antagonists. Trends Pharmacol Sci 11:2533.

Wenthold RJ, Yokotani N, Doi K, Wada K (1992) Immunochemical characterization of the non-NMDA glutamate receptor using subunitspecific antibodies. J Biol Chem 267:501-507.

Werner P, Voigt M, Keinänen K, Wisden W, Seeburg PH (1991) Cloning of a putative high-affinity kainate receptor expressed predominantly in hippocampal CA3 cells. Nature 351:742-744.

Wilson CJ (1986) Postsynaptic potentials evoked in spiny neostriatal projection neurons by stimulation of ipsilateral and contralateral neocortex. Brain Res 367:201-213.

Wilson JA, Doyle TJ, Lau Y-S (1990) MPTP, MPDP+ and MPP+ cause decreases in dopamine content in mouse brain slices. Neurosci Lett 108:213-218.

Wood JG, Wallace RW, Whitaker JN, Cheung WY (1980) Immunocytochemical localization of calmodulin and a heat-labile calmodulin-binding protein $\left(\mathrm{CaM}-\mathrm{BP}_{80}\right)$ in basal ganglia of mouse brain. $\mathbf{J}$ Cell Biol 84:66-76.

Yang CR, Mogenson GJ (1984) Electrophysiological responses of neurones in the nucleus accumbens to hippocampal stimulation and the attenuation of the excitatory responses by the mesolimbic dopaminergic system. Brain Res 324:69-84.

Yim CY, Mogenson GJ (1986) Mesolimbic dopamine projection modulates amygdala-evoked EPSP in nucleus accumbens neurons: an in vivo study. Brain Res 369:347-352.

Young AB, Penney JB, Dauth GW, Bromberg MB, Gilman S (1983) Glutamate or aspartate as a possible neurotransmitter of cerebral corticofugal fibers in the monkey. Neurology 33:1513-1516.

Young AB, Dauth GW, Hollingsworth Z, Penney JB, Kaatz K, Gilman S (1990) Quisqualate- and NMDA-sensitive $\left[{ }^{3} \mathrm{H}\right]$ glutamate binding in primate brain. J Neurosci Res 27:512-521. 